\title{
Relasi Dosen dan Mahasiswa di Perguruan Tinggi Islam
}

\author{
Ismail Suardi Wekke \\ Email: iswekke@gmail.com
}

Kajian Adawiyah (2019) menunjukkan bahwa tidak saja soal kemampuan dosen tetapi ini akan memengaruhi minat mahasiswa dalam belajar. Sementara itu, ada pula yang menjadi perhatian dimana dosen menjadi role model bagi mahasiswa yang akan membantu mereka dalam proses belajar mengajar. Termasuk dalam urusan skripsi dan juga bimbingan KKN. Kendala yang wujud saat ini dimana digambarkan Hidayat (2017) bahwa ada perspektif yang berbeda antara mahasiswa dan dosen dalam proses komunikasi sehingga terkadang terjadi hubungan yang tidak harmonis. Secara konseptual dikemukakan Ardianingsih \& Yunitarini (2015) bahwa sebagai dosen terikat pada etika dan juga kaitan dengan profesi. Olehnya, penelitian ini akan mengekplorasi bagaimana relasi mahasiswa dan dosen di perguruan tinggi Islam.

\section{Daftar Pustaka}

Adawiyah, R. (2019). Peningkatan Hasil Belajar Pendidikan Agama Islam Mahasiswa Melalui Kompetensi Profesional Dosen dan Minat Belajar Mahasiswa. Andragogi: Jurnal Pendidikan Islam dan Manajemen Pendidikan Islam, 1(1), 131-148.

Ardianingsih, A., \& Yunitarini, S. (2015). Etika, Profesi Dosen Dan Perguruan Tinggi: Sebuah Kajian Konseptual. Jurnal Ekonomi Dan Bisnis, 10(1).

Hidayat, R. (2017). Perilaku Etis Dosen Dalam Perspektif Efikasi Diri, Kepemimpinan, Dan Komunikasi Interpersonal. Pedagonal: Jurnal Ilmiah Pendidikan, 1(1), 37-44. 